\author{
Michał Chmiela)*, Eugeniusz Nowak $^{\mathrm{b})}$ \\ a) Scientific and Research Centre for Fire Protection - National Research Institute / Centrum Naukowo-Badawcze Ochrony \\ Przeciwpożarowej im. Józefa Tuliszkowskiego - Państwowy Instytut Badawczy \\ b) WS University in Dąbrowa Górnicza / Akademia WSB w Dąbrowie Górniczej \\ Corresponding author / Autor korespondencyjny: mchmiel@cnbop.pl
}

\title{
Acquisition of Field Logistic and Medical Resources in Long-term Rescue Operations
}

\section{Pozyskiwanie terenowych zasobów logistycznych i medycznych w dtugotrwałych akcjach ratowniczych}

\begin{abstract}
Aim: The aim of this article is to present effective procedures for acquiring logistic and medical field resources, which include appropriate operating procedures for the State Fire Service (SFS) units during the planning of long-term operations and during their execution.

Methodology: In both of the above studies, theoretical (analysis, synthesis and analogies) and empirical methods were used in the research process. The latter involved primarily the survey method, including interviews and questionnaires. In an effort to answer the first question, theoretical and empirical methods were used in the research process. Among the theoretical methods, the main ones were: 1) the analytical method, used to critically analyse literature on the organisation of logistic and medical security of military units; 2) the analogy method, was used for the logistic and medical needs of SFS units in long-term rescue operations, based on similarities with the logistic and medical needs of military units in combat operations and injured civilians; 3) the synthetic method, which was used to formulate conclusions (proposals regarding the logistic and medical needs of SFS units in long-term rescue operations) obtained by inductive reasoning and deductive reasoning, as well as by analogy.

Results: The study showed many shortcomings (difficulties) related to the acquisition of field resources, which occurred in long-term rescue operations conducted so far in Poland. The main ones were caused by the lack of appropriate regulations regarding: financing rescue operations; division of powers between SFS management and local public administration bodies in acquiring these resources; bonuses for business entities for maintaining readiness to carry out logistic tasks for SFS units.

In every system, even a well-organised one, there is certain inertia. The experience of organising logistic and medical security for SFS units in long-term rescue operations conducted in recent decades in Poland indicates that this also applies to acquiring field resources. As a result, a certain amount of time is needed for its full activation.

Conclusions: According to the authors, the study results and proposals based on them are innovative. Their application by the State Fire Service may significantly improve the logistic and medical security process of rescue units in long-term operations, and as a consequence increase the effectiveness of conducting these operations.

Keywords: State Fire Service units, long-term rescue operations, local logistic and medical resources Type of article: original scientific article
\end{abstract}

Received: 05.12.2019; Reviewed: 23.01.2020; Accepted: 28.02.2020;

Authors' ORCID IDs: M. Chmiel - 0000-0002-7364-6529; E. Nowak - 0000-0002-7310-3567;

Percentage contribution: The authors contributed equally to this article;

Please cite as: SFT Vol. 55 Issue 1, 2020, pp. 124-140, https://doi.org/10.12845/sft.55.1.2020.8;

This is an open access article under the CC BY-SA 4.0 license (https://creativecommons.org/licenses/by-sa/4.0/).

\begin{abstract}
ABSTRAKT
Cel: Zaprezentowanie skutecznych procedur pozyskiwania zasobów terenowych na potrzeby zabezpieczenia logistycznego i medycznego jednostek Państwowej Straży Pożarnej (PSP) podczas długotrwałych akcji ratowniczych.

Wprowadzenie: Długotrwałe akcje ratownicze generują szeroką gamę potrzeb logistycznych i medycznych. Jednak do tych akcji dochodzi relatywnie rzadko (stanowią one od 5 do 10\% wszystkich akcji ratowniczych prowadzonych przez jednostki PSP w Polsce). Także ze względów ekonomicznych potencjał logistyczny i medyczny jednostek PSP przystosowany jest do realizacji zadań głównie w działaniach krótkotrwałych, czyli trwających nie dłużej niż 6 godzin. Wskutek tego w długotrwałych akcjach zabezpieczenie logistyczne i medyczne jednostek PSP wymaga skorzystania z terenowych zasobów logistycznych i medycznych (środków zaopatrzenia oraz usług logistycznych i medycznych) pozyskiwanych z gospodarki narodowej. Z analizy i oceny długotrwałych akcji ratowniczych prowadzonych w Polsce w minionych dziesięcioleciach wynika, że w procesie pozyskiwania zasobów terenowych
\end{abstract}


pojawia się wiele mankamentów. Do głównych należą: długi czas uruchamiania dostaw środków zaopatrzenia i uruchamiania usług przez podmioty gospodarcze oraz kłopoty z ich egzekwowaniem w weekendy, opóźnienia w dostawach i usługach, brak procedur ustalania kosztów poniesionych przez podmioty gospodarcze podczas świadczenia tzw. niewymiernych usług logistycznych, konieczność ścisłego przestrzegania postanowień ustawy o zamówieniach publicznych podczas opracowywania planów pozyskiwania zasobów terenowych, brak skutecznych finansowych i pozafinansowych metod motywacji podmiotów gospodarczych - dostawców środków zaopatrzenia oraz świadczących usługi logistyczne. Ponadto sporadyczny charakter akcji długotrwałych powoduje, że organy logistyczne PSP mają relatywnie małe doświadczenie w pozyskiwaniu zasobów terenowych dla potrzeb zabezpieczenia logistycznego i medycznego jednostek PSP. Brakuje przede wszystkim dobrych praktyk związanych z opracowywaniem planów pozyskiwania zasobów terenowych (są one częścią składową planów ratowniczych) oraz procedur ich realizacji w akcjach ratowniczych. Świadczy o tym m.in. bardzo skromna literatura przedmiotu. Głównym źródłem wiedzy w tym zakresie jest bezpośredni przekaz funkcjonariuszy PSP, którzy posiadają doświadczenie w organizowaniu zabezpieczenia logistycznego i medycznego w akcjach długotrwałych. Problem ten można rozwiązać m.in. poprzez wdrożenie do praktyki służbowej PSP odpowiednich procedur pozyskiwania zasobów terenowych z gospodarki narodowej. Dotyczyłyby one działania organów kierowania PSP na etapie planowania akcji długotrwałych oraz w trakcie ich prowadzenia.

Metodologia: Zaproponowane w artykule rozwiązania bazują na wynikach badań autorskich, zawartych w literaturze załącznikowej. W trakcie badań stosowano metody teoretyczne (analizy, syntezy i analogii) oraz empiryczne. W ostatnich dominowała metoda sondażowa, a w jej ramach techniki wywiadu i ankietowania.

Wnioski: Według opinii autorów propozycje powstałe na podstawie uzyskanych wyników badań mają charakter nowatorski. Stosowanie w praktyce służbowej PSP zaproponowanych rozwiązań w sposób znaczący może usprawnić proces zabezpieczenia logistycznego i medycznego jednostek PSP prowadzących długotrwałe akcje ratownicze. W konsekwencji może pozytywnie wpływać na efektywność prowadzenia tych akcji.

Słowa kluczowe: jednostki Państwowej Straży Pożarnej, długotrwała akcja ratownicza, terenowe zasoby logistyczne i medyczne

Typ artykułu: oryginalny artykuł naukowy

Przyjęty: 05.12.2019; Zrecenzowany: 23.01.2020; Zaakceptowany: 28.02.2020;

Identyfikatory ORCID autorów: M. Chmiel - 0000-0002-7364-6529; E. Nowak - 0000-0002-7310-3567;

Procentowy wkład merytoryczny: Autorzy wnieśli równy wkład merytoryczny w powstanie artykułu;

Proszę cytować: SFT Vol. 55 Issue 1, 2020, pp. 124-140, https://doi.org/10.12845/sft.55.1.2020.8;

This is an open access article under the CC BY-SA 4.0 license (https://creativecommons.org/licenses/by-sa/4.0/).

\section{Introduction}

Rescue operations involve organised efforts to fight fires and floods, as well as technical, chemical, environmental and medical rescue. In Poland, the main system coordinating these efforts is the National Firefighting Rescue System (NFRS). Its central authority is the State Fire Service (SFS), supported by Voluntary Fire Service (VFS) units. Furthermore, arrangements have been made for the system to include other rescue units (public services, inspections, guards).

Rescue units conduct short-term rescue operations - up to six hours - and long-term operations, lasting more than 6 hours, as well as rescue operations including at least one cycle of scuba diving. Rescue operations are organised and managed entirely by the SFS. Each operation requires logistic and medical resources, including extensive supplies and services.

Supplies include primarily drinking water and non-potable water, food, articles of everyday use, liquid fuels and lubricants, technical supplies (spare parts), medical materials and specialist supplies depending on the type of the rescue operation (e.g. fire-extinguishing agents, flood protection materials and equipment, sorbents, neutralisers, etc.).

Logistic services include mainly basic services (catering, accommodation, bathing facilities) and specialised services (primarily transport and refurbishment), whose scale and method of provision depend on the type of the rescue operation.

Medical services in the area of rescue operations include qualified first aid, first medical aid and medical evacuation.

Long-term rescue operations in Poland are relatively rare, representing only from 5 to 10 percent of all rescue operations led by SFS units. However, it is also for economic reasons that the

\section{Wprowadzenie}

Działania ratownicze to zorganizowane czynności prowadzone w ramach : walki z pożarami, powodzią, ratownictwa technicznego, chemicznego, ekologicznego i medycznego. W Polsce głównym systemem koordynującym prowadzenie tych działań jest KSRG. Jego centralnym organem jest PSP, wspierana przez jednostki OSP. Ponadto, na zasadzie zawartych porozumień, w systemie uczestniczą również inne jednostki ratownicze (publiczne służby, inspekcje, straże).

Jednostki ratownicze prowadzą akcje ratownicze krótkotrwałe - do 6 godzin - i długotrwałe, czyli takie, które trwają ponad 6 godzin, a także akcje ratownicze obejmujące co najmniej jeden cykl nurkowania. Akcja ratownicza to działanie organizowane i kierowane w całości przez PSP. Każde wymaga zaplecza logistycznego i medycznego obejmującego szeroki asortyment środków zaopatrzenia oraz usług.

Do środków zaopatrzenia zalicza się przede wszystkim: wodę do picia i celów gospodarczych, artykuły żywnościowe, artykuły powszechnego użytku, paliwa płynne i smary, techniczne środki zaopatrzenia (części zamienne), materiały medyczne oraz specjalistyczne środki zaopatrzenia zależne od rodzaju prowadzonej akcji ratowniczej (np. środki gaśnicze, środki i sprzęt przeciwpowodziowy, sorbenty, neutralizatory itp.).

Usługi logistyczne to głównie usługi gospodarczo-bytowe (gastronomiczne, kwaterunkowe i kąpielowe) oraz specjalistyczne (głównie transportowe i remontowe), których skala i sposób realizacji zależą od rodzaju prowadzonej akcji ratowniczej.

Usługi medyczne w rejonie prowadzenia akcji ratowniczej obejmują kwalifikowaną pierwszą pomoc, pierwszą pomoc lekarską oraz ewakuację medyczną. 
logistic and medical potential of SFS units is adapted chiefly to provide logistic and medical backup for these units, primarily for short-term rescue operations. Hence, when arranging for this type of backup in long-term operations, one of the key aspects is to ensure the availability of field logistic and medical resources (supplies and logistic and medical services) acquired from the national economy, i.e. from local business entities. Also, due to the sporadic nature of long-term operations, the commanders and logistic authorities of SFS have relatively little experience in acquiring logistic and medical resources. This is reflected, among other things, by the very scarce literature on the subject. The main source of knowledge on this subject are briefings by SFS officers who have certain experience in providing the logistic and medical backup of FSF units in long-term operations.

In this light, the question arose of how to ensure continuity of field logistics and medical resources necessary to provide the logistic and medical backup of SFS units involved in long-term rescue operations. There was a particularly urgent need, which prompted this study, to develop effective procedures for acquiring these resources. For the purposes of this study, the authors defined effectiveness as the ability to perform logistic and medical tasks according to the " $4 \times \mathrm{R}$ " rule, i.e. in the right time, in the right amount, with the right quality and in the right place. The authors believe such efficiency encompasses appropriate projects and procedures undertaken and followed by SFS authorities, both at the stage of planning and in the course of conducting long-term rescue operations. Hence, the study was guided by two working hypotheses.

The first one assumes that solutions representing "good practices" for organising logistic and medical backup should be looked for among military logisticians, who review their procedures on a regular basis during frequent exercises and missions abroad, as well as in the theory and practice of crisis logistics.

According to the second hypothesis, a rich source of knowledge of how to organise logistic and medical backup for SFS units in long-term rescue operations can be found in the experience of SFS officers who have experience in such operations.

\section{Methodology}

The study aimed to answer the following fundamental questions:

1. What are the logistic and medical needs of SFS units in long-term rescue operations?

2. How can the acquisition of field logistic and medical resources be facilitated to provide logistic and medical backup for SFS units in long-term rescue operations?

Theoretical and empirical methods were used to answer the first question. The former included primarily:

- a critical review of literature on the organisation of logistic and medical backup for military units (of the
Długotrwałe akcje ratownicze na obszarze Polski prowadzone są relatywnie rzadko, bowiem stanowią od 5 do $10 \%$ wszystkich akcji ratowniczych dowodzonych przez jednostki PSP. Także z przyczyn ekonomicznych, potencjał logistyczny i medyczny jednostek PSP przystosowany jest głównie do realizacji zabezpieczenia logistycznego i medycznego tych jednostek głównie w krótkotrwałych akcjach ratowniczych. Dlatego organizacja tego rodzaju zabezpieczenia w akcjach długotrwałych musi bazować w dużej mierze na terenowych zasobach logistycznych i medycznych (środków zaopatrzenia oraz usług logistycznych i medycznych) pozyskiwanych z gospodarki narodowej, czyli od działających w terenie podmiotów gospodarczych. Sporadyczny charakter akcji długotrwałych powoduje, że dowódcy i organy logistyczne PSP mają małe doświadczenie w pozyskiwaniu terenowych zasobów logistycznych i medycznych. Świadczy o tym m.in. bardzo skromna literatura przedmiotu. Głównym źródłem wiedzy w omawianym zakresie jest słowny przekaz funkcjonariuszy PSP, którzy uczestniczyli w organizacji zabezpieczenia logistycznego i medycznego jednostek PSP w akcjach długotrwałych.

Zarysowany problem zrodził pytanie o to, jak zapewnić ciągłość pozyskiwania terenowych zasobów logistycznych i medycznych niezbędnych do zabezpieczenia logistycznego i medycznego jednostek PSP prowadzących długotrwałe akcje ratownicze. Szczególnie pilną potrzebą, stanowiącą równocześnie przyczynę podjęcia badań, było wypracowanie skutecznych procedur pozyskiwania tych zasobów. Przez skuteczność w akcjach ratowniczych autorzy rozumieją zdolność do realizacji zadań logistycznych i medycznych według reguły " $4 \times$ W", tj.: we właściwym czasie, we właściwych ilościach, o właściwej jakości oraz we właściwym miejscu. Na tę skuteczność, według opinii autorów, składają się odpowiednie przedsięwzięcia i procedury działania organów kierowania PSP na etapie planowania długotrwałych akcji ratowniczych oraz w trakcie ich prowadzenia. Wobec powyższego kierunek prowadzonym badaniom nadawały dwie hipotezy robocze.

Pierwsza zakłada, że rozwiązań zawierających przykłady „dobrej praktyki" w organizacji zabezpieczenia logistycznego i medycznego należy poszukiwać u logistyków wojskowych, którzy swoje procedury weryfikują w trakcie często odbywanych ćwiczeń oraz podczas misji zagranicznych, a także w teorii i praktyce logistyki kryzysowej.

Zgodnie z drugą, bogatego źródła wiedzy na temat organizacji zabezpieczenia logistycznego i medycznego jednostek PSP w długotrwałych akcjach ratowniczych należy upatrywać w doświadczeniu funkcjonariuszy PSP, którzy uczestniczyli w takich akcjach.

\section{Metodyka prowadzonych badań}

Badania miały na celu udzielenie odpowiedzi na dwa podstawowe pytania:

1. Jakie są potrzeby logistyczne i medyczne jednostek PSP w długotrwałych akcjach ratowniczych?

2. Jak można usprawnić pozyskiwanie terenowych zasobów logistycznych i medycznych na potrzeby zabezpieczenia logistycznego i medycznego jednostek PSP w długotrwałych akcjach ratowniczych?

Dążąc do udzielenia odpowiedzi na pytanie pierwsze wykorzystano metody teoretyczne i empiryczne. Do tych pierwszych zaliczały się głównie: 
Polish Land Forces) in combat operations, and the logistic backup for civilian casualties in crisis situations [1-5],

- analogy, which was used to formulate proposals regarding the logistic and medical needs of SFS units in long-term rescue operations, by analogy to the logistic and medical needs of military units (of the Polish Lad Forces) in combat operations, and civilian casualties in crisis situations,

- synthesis, which was employed to formulate conclusions (proposals regarding the logistic and medical needs of SFS units in long-term rescue operations) drawn by inductive and deductive reasoning, as well as by analogy.

The core empirical method used was the survey method, which included the interview and questionnaire techniques. The interviews and questionnaires were conducted among experienced central- and regional-level SFS officers with long time in service.

The questions in the interview pertained primarily to:

- the types and urgency levels of the logistic and medical needs of SFS units in long-term rescue operations,

- the subject of the logistic and medical backup of SFS units in long-term rescue operations,

- the factors (projects) determining the organisation of the logistic and medical backup for SFS units in long-term rescue operations.

The questions in the questionnaire pertained to:

- the types and urgency levels of the logistic and medical needs of SFS units in long-term rescue operations,

- the reasons for and the necessity to use field logistic and medical resources as the logistic and medical backup of FSF units in long-term rescue operations,

- the methods of organising the acquisition of field logistic and medical resources.

In order to answer the second question (i.e. how to facilitate the acquisition of field logistic and medical resources to provide the logistic and medical backup of SFS units in longterm rescue operations), the study used the analogy and the survey methods.

The analogy method was employed to develop procedures associated with the preparation by SFS authorities of a local resource acquisition plan for the purposes of providing the logistic backup of SFS units in rescue operations projected to be long-term. In this case, the authors followed the template of crisis management procedures - proven by the exercise practice of the National Defence University of Warsaw (currently the War Studies Academy) and the Higher School of Management and Entrepreneurship (the Warsaw Branch) - applied in decision-making, developing the intent to conduct rescue operations, and establishing plans to conduct such operations [4], [6]

In order to identify what determinants ensure the effective acquisition of local logistic and medical resources from the national economy, the authors employed primarily the survey method, including the interview and questionnaire techniques. Respondents (experts) included experienced SFS officers who
- analiza krytyczna literatury przedmiotu traktującej o organizacji zabezpieczenia logistycznego i medycznego jednostek wojskowych (Wojsk Lądowych) w działaniach bojowych oraz zabezpieczenia logistycznego ludności poszkodowanej w sytuacjach kryzysowych [1-5],

- analogia, którą wykorzystano do formułowania propozycji odnoszących się do potrzeb logistycznych i medycznych jednostek PSP w długotrwałych akcjach ratowniczych, na zasadzie podobieństwa z potrzebami logistycznymi i medycznymi jednostek wojskowych (Wojsk Lądowych) w działaniach bojowych oraz ludności poszkodowanej w sytuacjach kryzysowych,

- synteza, która służyła do formułowania wniosków (propozycji dotyczących potrzeb logistycznych i medycznych jednostek PSP w długotrwałych akcjach ratowniczych) uzyskiwanych w drodze rozumowania indukcyjnego i dedukcyjnego, a także przez analogię.

Natomiast za podstawową metodę empiryczną posłużyła metoda badania opinii (sondażu), w której wykorzystano techniki wywiadu i ankietowania. Respondentami byli doświadczeni funkcjonariusze PSP szczebla centralnego i wojewódzkiego o wieloletnim stażu służby.

Pytania zawarte w kwestionariuszu wywiadu dotyczyły przede wszystkim:

- rodzajów i stopnia pilności potrzeb logistycznych i medycznych jednostek PSP w długotrwałych akcjach ratowniczych,

- przedmiotu zabezpieczenia logistycznego i medycznego jednostek PSP w długotrwałych akcjach ratowniczych,

- czynników (przedsięwzięć) determinujących organizację zabezpieczenia logistycznego i medycznego jednostek PSP w długotrwałych akcjach ratowniczych.

Pytania zawarte $w$ kwestionariuszu ankiety poruszały kwestie:

- rodzaju i stopnia pilności potrzeb dot. zaopatrzenia oraz usług logistycznych i medycznych dla jednostek PSP w długotrwałych akcjach ratowniczych,

- przyczyn i konieczności korzystania w długotrwałych akcjach ratowniczych, w ramach zabezpieczenia logistycznego i medycznego jednostek PSP, z terenowych zasobów logistycznych i medycznych,

- sposobów organizacji pozyskiwania terenowych zasobów logistycznych i medycznych w długotrwałych akcjach ratowniczych.

Aby udzielić odpowiedzi na pytanie drugie (tj. jak usprawnić pozyskiwanie terenowych zasobów logistycznych i medycznych dla potrzeb zabezpieczenia logistycznego i medycznego jednostek PSP w długotrwałych akcjach ratowniczych), w procesie badań wykorzystywano metodę analogii oraz metodę sondażu.

Metoda analogii służyła do wypracowania procedur związanych z przygotowaniem przez organy PSP planu pozyskiwania zasobów terenowych dla potrzeb zabezpieczenia logistycznego jednostek PSP w prognozowanych długotrwałych akcjach ratowniczych. W tym przypadku za wzorzec posłużyły zweryfikowane w praktyce ćwiczebnej Akademii Obrony Narodowej (obecnie ASzWoj) i Wyższej Szkoły Zarządzania i Przedsiębiorczości (Wydział Zamiejscowy w Warszawie) procedury zarządzania 
had participated in the firefighting operation during the 1992 forest fire in Kuźnia Raciborska, the 1997 flood rescue operation in Lower Silesia, the rescue operation during the 2006 construction accident in Chorzów, and in the 2010 flood rescue operation in the area of Sandomierz.

The questions in the questionnaire pertained primarily to:

- the procedures for acquiring supplies and commissioning logistic and medical services used in long-term rescue operations in which the respondents were involved,

- the scope of logistic cooperation between SFS authorities, local crisis management authorities, and external suppliers and service providers in long-term rescue operations in which the respondents were involved,

- the methods to provide incentives to external suppliers and service providers in long-term rescue operations in which the respondents were involved,

- the methods used to settle payments due to external suppliers and service providers in long-term rescue operations in which the respondents were involved.

The questionnaire included questions relating primarily to:

- the methods of facilitating (improving) the acquisition of local logistic and medical resources used in long-term rescue operations in which the respondents were involved,

- the expected scope of the logistic and medical autonomy of SFS units assigned with long-term rescue operations. kryzysowego stosowane podczas podejmowania decyzji, wypracowywania zamiaru na prowadzenie akcji ratowniczych oraz opracowania planów prowadzenia tych akcji [4], [6].

W procesie poszukiwania determinantów zapewniających skuteczność pozyskiwania terenowych zasobów logistycznych i medycznych z gospodarki narodowej dominowała metoda sondażowa, a w ramach niej techniki wywiadu i ankietowania. Respondentami (ekspertami) byli doświadczeni funkcjonariusze PSP, którzy brali udział w: akcji gaśniczej podczas pożaru lasu w Kuźni Raciborskiej w 1992 roku, akcji powodziowej na Dolnym Śląsku w 1997 roku, akcji ratowniczej podczas katastrofy budowlanej w Chorzowie w 2006 roku oraz akcji powodziowej w rejonie Sandomierza w 2010 roku.

Zawarte w kwestionariuszu wywiadu pytania dotyczyły przede wszystkim:

- usług logistycznych i medycznych stosowanych w długotrwałych akcjach ratowniczych, w których uczestniczyli respondenci,

- przedmiotu współdziałania logistycznego pomiędzy organami kierowania PSP, terenowymi organami zarządzania kryzysowego oraz dostawcami i usługodawcami zewnętrznymi w długotrwałych akcjach ratowniczych, w których uczestniczyli respondenci,

- sposobów motywacji stosowanych wobec dostawców i usługodawców zewnętrznych w długotrwałych akcjach ratowniczych, w których uczestniczyli respondenci,

- zasad rozliczeń finansowych z dostawcami i usługodawcami zewnętrznymi stosowanych w długotrwałych akcjach ratowniczych, w których uczestniczyli respondenci.

W kwestionariuszu ankiety pytano natomiast przede wszystkim o:

- sposoby usprawniania (doskonalenia) procesu pozyskiwania terenowych zasobów logistycznych i medycznych w długotrwałych akcjach ratowniczych, w których uczestniczyli respondenci,

- pożądany zakres autonomiczności potencjału logistycznego i medycznego jednostek PSP kierowanych do prowadzenia długotrwałych akcji ratowniczych.

\section{Wyniki badań}

Potrzeby logistyczne i medyczne jednostek PSP w długotrwałych akcjach ratowniczych zależą od liczby osób zaangażowanych w akcje, a także czynników bytowych, fizjologicznych, sanitarno-higienicznych, atmosferycznych i przeciwepidemicznych. W bardzo dużym stopniu uzależnione są także od stosowanych technik ratowniczych oraz użytego sprzętu technicznego, czyli od rodzaju prowadzonej akcji. Stąd zwykle dzielone są na: grupę potrzeb stałych i grupę potrzeb zmiennych. Kryterium takiego podziału wynika z asortymentu zużywanych środków zaopatrzenia, rodzaju świadczonych usług oraz rodzaju prowadzonej akcji ratowniczej.

Grupę potrzeb stałych tworzą potrzeby niezależne od rodzaju prowadzonej akcji ratowniczej. Oznacza to, że występują one we wszystkich prowadzonych akcjach. Zwykle są to dostawy. wody pitnej (napojów) i wody do celów gospodarczych, artykułów żywnościowych, artykułów powszechnego użytku, paliw płynnych, technicznych środków zaopatrzenia (części zamiennych) oraz 
accommodation and bathing facilities), as well as transport, refurbishment and transshipment services, and medical aid.

Variable needs are needs which depend on the type of the rescue operation, i.e. on specialist supplies and logistic services. During firefighting operations, these usually include supplies of firefighting water and fire-extinguishing sand, foaming agents, fire-extinguishing gases and powders, as well as the restoration (repair) of firefighting equipment. For flood operations, these include specialised personal protective equipment, flood protection measures (sand bags, sand, foil, inflatable flood barriers, personal technical equipment, etc.) and the restoration (repair) of flood control equipment. During environmental and chemical disasters, the required supplies include neutralisers, sorbents, decontamination solutions and the restoration (repair) of chemical equipment, etc.

In long-term rescue operations, there are certain standards for the supplies and logistic services provided as the logistic backup of SFS units. The contrary applies to the logistic backup of civilian casualties, where reduced, and even critical, standards are allowed in extreme cases. The urgency of the logistic and medical needs of SFS units in long-term rescue operations is shown in Figure 1. materiałów medycznych. Do tej grupy należą także usługi: gospodarczo-bytowe (gastronomiczne, kwaterunkowe oraz kąpielowe), transportowe, remontowe oraz usługi przeładunkowe. Zalicza się do nich również pomoc medyczną.

Grupa potrzeb zmiennych odnosi się do potrzeb zależnych od rodzaju prowadzonej akcji ratowniczej, czyli specjalistycznych środków zaopatrzenia oraz specjalistycznych usług logistycznych. Podczas akcji gaśniczej są to zwykle dostawy: wody gaśniczej, piasku gaśniczego, środków pianotwórczych, gazów i proszków gaśniczych, a także remont (naprawa) sprzętu gaśniczego. W akcji powodziowej są to dostawy: specjalistycznej odzieży ochronnej, środków przeciwpowodziowych (worki do piasku, piasek, folia, rękawy przeciwpowodziowe, indywidualny sprzęt techniczny itp.), a także remont (naprawa) sprzętu przeciwpowodziowego. Podczas akcji chemiczno-ekologicznej są to dostawy: neutralizatorów, sorbentów, roztworów dekontaminacyjnych, a także remont (naprawa) sprzętu chemicznego itp.

W długotrwałych akcjach ratowniczych w procesie zabezpieczenia logistycznego jednostek PSP obowiązują pełne normy zaopatrzenia i świadczenia usług logistycznych. Przeciwnie dzieje się podczas zabezpieczenia logistycznego ludności poszkodowanej - tu w skrajnych przypadkach dopuszcza się stosowanie norm zmniejszonych, a nawet krytycznych. Stopień pilności realizacji potrzeb logistycznych i medycznych jednostek PSP w długotrwałych akcjach ratowniczych przedstawia rycina 1.

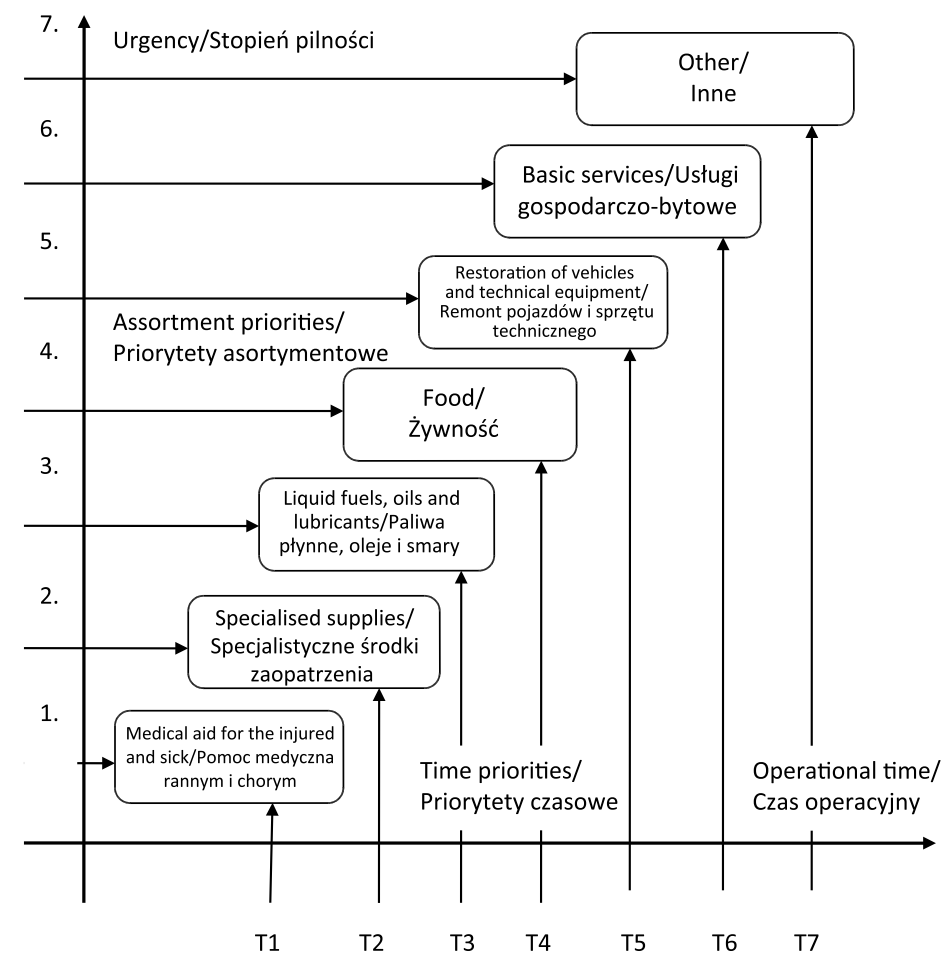

Figure 1. The urgency of the logistic and medical needs of SFS units in long-term rescue operations Rycina 1. Stopień pilności realizacji potrzeb logistycznych i medycznych jednostek PSP w długotrwałych akcjach ratowniczych

Source: A system for the comprehensive logistic backup of multi-agent rescue operations, Task 5. Managing logistic resources in rescue operations, Stage I - 5.1. Defining methods to calculate the logistic needs of units involved in multi-agent rescue operations, E. Nowak (ed.), Wyd. AON, Warsaw 2014 [7, p. 52].

Źródło: System kompleksowego zabezpieczenia logistycznego wielopodmiotowych akcji ratowniczych, Zadanie 5. Zarządzanie zasobami logistycznymi w akcjach ratowniczych, Etap I - 5.1. Określenie sposobów kalkulacji potrzeb logistycznych jednostek uczestniczących w wielopodmiotowych akcjach ratowniczych, E. Nowak (red.), Wyd. AON, Warszawa 2014 [7, s. 52] 
The study confirmed that ensuring continuous supplies of local logistic and medical resources could be compared to solving a problem with multiple unknowns. These include primarily the expected type of future long-term rescue operations, their scale and the available resource of local logistic and medical infrastructure, as well as the preparation of business entities and providing them with incentives to deliver supplies and to provide logistic and medical services to SFS units conducting long-term rescue operations.

The scale of long-term rescue operations was assessed mainly based on the amount of deployed rescue forces and measures, the size of the area in which the operation was conducted and the duration of the operation.

The available resource of logistic and medical infrastructure was reviewed in terms of the availability of supplies and logistic and medical services required to arrange for the logistic backup of SFS units engaged in long-term operations.

In the assessment of the preparation of business entities to provide supplies and logistic and medical services to SFS units, the authors assessed their readiness to cooperate "at all times of the day and night", i.e. continuously, all day long, as well as on weekends and holidays (usually, business entities are prepared to cooperate on a single-shift basis, mainly during the day from Monday to Friday). It was important here to consider the issue of providing effective incentives (both financial and non-financial) to business entities - this problem should be solved already at the stage of planning the acquisition of local resources.

Planning the acquisition of logistic and medical resources from the national economy to provide the logistic and medical backup of SFS units in long-term rescue operations should be part of the process of developing rescue plans, with the involvement of all the departments of the SFS headquarters (District Headquarters of the SFS - DH SFS, the Regional Headquarters of the SFS - RH SFS), including the Logistics Department. This task is based on multiple projections, thus requiring procedures to eliminate as many errors as possible. The authors claim that this is ensured by the decision-making process model which has been in place at the Armed Forces of the Republic of Poland for many years, and the so-called classic planning procedure. Developed by SFS Headquarters, such rescue plans (rescue plans are developed by DH SFS and RH SFS) may be designed as shown in Figure 2.

From the logistic point of view, the SFS Commandant's decision-making process associated with the development of a rescue plan should be divided into two parallel parts - the operational and the logistic part.

The operational part relates to devising rescue (operational) tasks associated with conducting projected operations which, in turn, determine such aspects as the needs for local logistic and medical resources.

The logistic part involves the outlining of logistic and medical tasks - appropriate for operational tasks - and the manner of their implementation. In the logistics community, the outcome of these works is called the logistic substantive contribution to the SFS Commandant's decision-making process. It assumes the following task allocation and performance:
Badania potwierdziły, że zapewnienie ciągłości pozyskiwania zasobów logistycznych i medycznych od terenowych podmiotów gospodarczych można porównać do rozwiązywania zadania z wieloma niewiadomymi. Głównymi z nich są: przewidywany rodzaj przyszłych długotrwałych akcji ratowniczych, ich rozmach oraz zasobność terenowej infrastruktury logistycznej i medycznej, a także przygotowanie podmiotów gospodarczych i ich motywowanie do realizacji dostaw zaopatrzenia oraz świadczenia usług logistycznych i medycznych na rzecz jednostek PSP prowadzących długotrwałe akcje ratownicze.

Rozmach długotrwałych akcji ratowniczych oceniany był głównie poprzez wielkość użytych sił i środków ratowniczych, rozmiar obszaru, na którym prowadzona była dana akcja, oraz czas jej trwania

Zasobność terenowej infrastruktury logistycznej i medycznej weryfikowana była pod kątem dostępności środków zaopatrzenia oraz usług logistycznych i medycznych niezbędnych do organizacji zabezpieczenia logistycznego jednostek PSP prowadzących akcję długotrwałą.

Przygotowanie podmiotów gospodarczych do realizacji dostaw zaopatrzenia oraz świadczenia usług logistycznych i medycznych jednostkom PSP poddawano ocenie, biorąc pod uwagę możliwość realizacji tych zadań „o każdej porze dnia i nocy”, czyli w sposób ciągły, przez całą dobę oraz w weekendy i święta (podmioty gospodarcze zwykle przygotowywane są do realizacji swoich zadań w systemie jednozmianowym, głównie w porze dziennej od poniedziałku do piątku). Ważny w związku z tym okazał się problem zapewnienia skutecznych środków motywacji (materialnej i pozamaterialnej) podmiotów gospodarczych, który powinien być rozwiązany już w okresie planowania pozyskiwania zasobów terenowych.

Planowanie pozyskiwania zasobów logistycznych i medycznych z gospodarki narodowej na potrzeby zabezpieczenia logistycznego i medycznego jednostek PSP w długotrwałych akcjach ratowniczych powinno stanowić część procesu opracowania planów ratowniczych. W ich przygotowaniu uczestniczą wszystkie piony funkcjonalne komendy PSP (KP PSP, KW PSP), w tym pion logistyki. Zadanie to bazuje na wielu prognozach, wobec czego wymaga stosowania procedur eliminujących możliwie jak największą liczbę błędów. W opinii autorów zapewnia to stosowany od wielu lat w Siłach Zbrojnych RP model procesu decyzyjnego oraz tzw. klasyczna procedura planowania. Podczas opracowywania przez komendy PSP planów ratowniczych (plany ratownicze opracowywane są w KP PSP i KW PSP) może on przybrać postać jak na rycinie 2.

$Z$ logistycznego punktu widzenia proces decyzyjny komendanta PSP związany z opracowaniem planu ratowniczego należy podzielić na dwie równoległe części - operacyjną i logistyczną.

Część operacyjna dotyczy wypracowania zadań ratowniczych (operacyjnych) związanych z prowadzeniem prognozowanych akcji, które $z$ kolei determinują m.in. potrzeby logistyczne w zakresie korzystania z terenowych zasobów logistycznych i medycznych.

Część logistyczna związana jest z określeniem zadań logistycznych i medycznych - adekwatnych do zadań operacyjnych - oraz sposobów ich realizacji. W środowisku logistyków efekt tych prac nazywany jest logistycznym wkładem merytorycznym w proces decyzyjny komendanta PSP. Zakłada on następujący podział i przebieg zadań: 


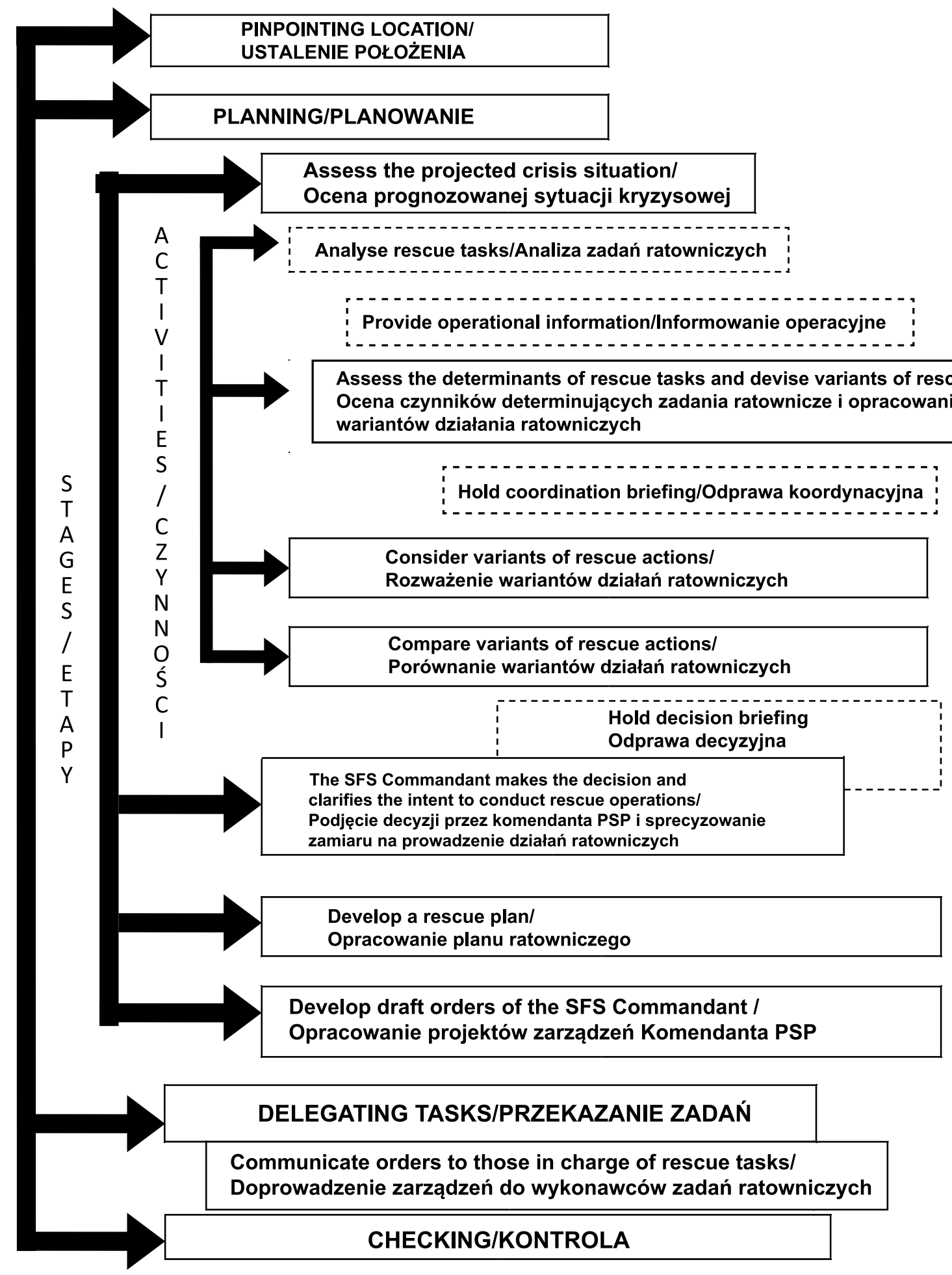

Figure 2. Postulated model of the SFS Commandant's decision-making process when developing a rescue plan Rycina 2. Postulatywny model procesu decyzyjnego komendanta PSP w czasie opracowania planu ratowniczego

Source: A system for the comprehensive logistic backup of multi-agent rescue operations. Task 5 Managing logistic resources in rescue operations. 5.3 . Develop a model for using logistic resources in rapidly changing multi-agent rescue operations, E. Nowak (ed.), Wyd. AON, Warsaw 2014, [8, p. 16]. Źródło: System kompleksowego zabezpieczenia logistycznego wielopodmiotowych akcji ratowniczych. Zadanie 5. Zarządzanie zasobami logistycznymi w akcjach ratowniczych. 5.3. Opracowanie modelu wykorzystania zasobów logistycznych w dynamicznie zmieniających się wielopodmiotowych akcjach ratowniczych, E. Nowak (red.), Wyd. AON, Warszawa 2014, [8, s. 16]. 
1. In the "pinpointing location" phase, the logistic authorities of the SFS Headquarters obtain, store, collate and process logistic information, including basic medical data required to develop a plan for acquiring logistic and medical resources from the national economy, among other tasks. This information is sourced from the internal (logistic) database, local government authorities, higher-level (superior) logistic authorities, neighbouring SFS and VFS Headquarters, local population and non-governmental organisations. Furthermore, it is obtained from specially arranged logistic reconnaissance operations conducted in the areas where long-term rescue operations are projected. A computer database is usually set up to store the obtained logistic and medical information.

2. In the "planning" phase, the logistics management authorities furnish the SFS Commandant with logistic and medical data required to:

- assess the projected rescue operations from the so-called "logistic point of view" (i.e. in terms of the conditions for organising and ensuring the logistic and medical backup of SFS units and the rescue entities that support them),

- make the decision and clarify the intent (express the will) as to the manner of conducting the projected rescue operations and arranging the logistic and medical backup of SFS units, and the other rescue units which support them,

- issue guidelines for developing a rescue plan (including logistic appendices thereto, such as the plan for acquiring local logistic and medical resources), as well as drafts of selected logistic operational orders for those in charge of rescue tasks and drafts of contracts with business entities for the provision of supplies and logistic and medical services.

3. In the "checking" phase, the logistics management authorities verify the usefulness of the planned logistic and medical tasks.

Their involvement in the SFS Commandant's decision-making process related to the development of a rescue plan is illustrated in the model presented in Figure 3.
1. W fazie "ustalenie położenia" logistyczne organy kierowania komendy PSP zajmują się pozyskiwaniem, gromadzeniem, porządkowaniem i odpowiednim przetwarzaniem informacji logistycznych, w tym również podstawowych danych medycznych, niezbędnych m.in. do opracowania planu pozyskiwania zasobów logistycznych i medycznych z gospodarki narodowej. Informacje te czerpane są z własnej (logistycznej) bazy danych, terenowych organów administracji publicznej, organów logistycznych wyższego szczebla (przełożonych), sąsiednich komend PSP oraz OSP, ludności miejscowej i organizacji pozarządowych. Pochodzą również ze specjalnie organizowanych rekonesansów logistycznych przeprowadzonych na prognozowanych obszarach prowadzenia długotrwałych akcji ratowniczych. Na potrzeby gromadzenia zdobytych informacji logistycznych i medycznych tworzona jest zwykle informatyczna baza danych.

2. W fazie "planowanie" logistyczne organy kierowania dostarczają komendantowi PSP dane logistyczne i medyczne niezbędne do:

- oceny prognozowanych akcji ratowniczych z tzw. "logistycznego punktu widzenia” (czyli pod kątem warunków organizacji i realizacji zabezpieczenia logistycznego i medycznego jednostek PSP oraz wspierających je podmiotów ratowniczych),

- podjęcia decyzji i sprecyzowaniu zamiaru (wyrażenia woli) co do sposobu prowadzenia prognozowanych akcji ratowniczych i organizacji w nich zabezpieczenia logistycznego i medycznego jednostek PSP oraz wspierających je innych jednostek ratowniczych,

- wydania wytycznych do opracowania planu ratowniczego (w tym jego logistycznych załączników funkcjonalnych, m.in. planu pozyskiwania terenowych zasobów logistycznych i medycznych), a także projektów wybranych logistycznych zarządzeń operacyjnych dla wykonawców zadań ratowniczych oraz umów z podmiotami gospodarczymi na dostawy środków zaopatrzenia i świadczenie usług logistycznych i medycznych.

3. W fazie "kontrola" logistyczne organy kierowania zajmują się weryfikacją użyteczności zaplanowanych zadań logistycznych i medycznych.

Udział logistycznych organów kierowania w procesie decyzyjnym komendanta PSP związanym z opracowaniem planu ratowniczego zilustrowano na modelu, który przedstawia rycina 3. 


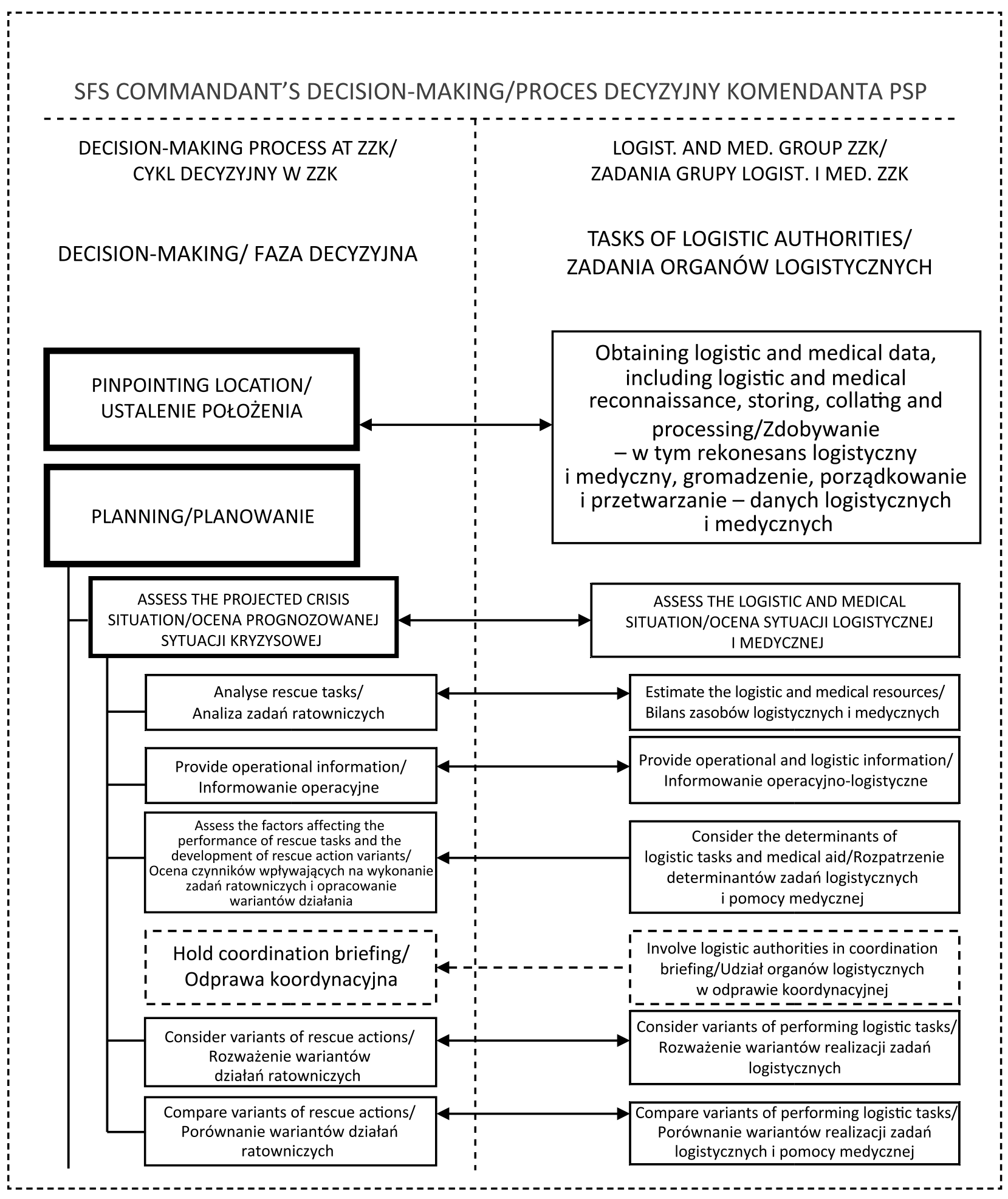

Figure 3. Postulated model of participation in logistics management authorities in the SFS Commandant's decision-making process Rycina 3. Postulatywny model udziału logistycznych organów kierowania w procesie decyzyjnym komendanta PSP w czasie opracowania planu ratowniczego

Source: A system for the comprehensive logistic backup of multi-agent rescue operations. Task 5 Managing logistic resources in rescue operations. 5.3 . Develop a model for using logistic resources in rapidly changing multi-agent rescue operations, E. Nowak (ed.), Wyd. AON, Warsaw 2014, [8, p. 24]. Źródło: System kompleksowego zabezpieczenia logistycznego wielopodmiotowych akcji ratowniczych. Zadanie 5. Zarządzanie zasobami logistycznymi w akcjach ratowniczych. 5.3. Opracowanie modelu wykorzystania zasobów logistycznych w dynamicznie zmieniających się wielopodmiotowych akcjach ratowniczych, E. Nowak (red.), Wyd. AON, Warszawa 2014, [8, s. 24]. 


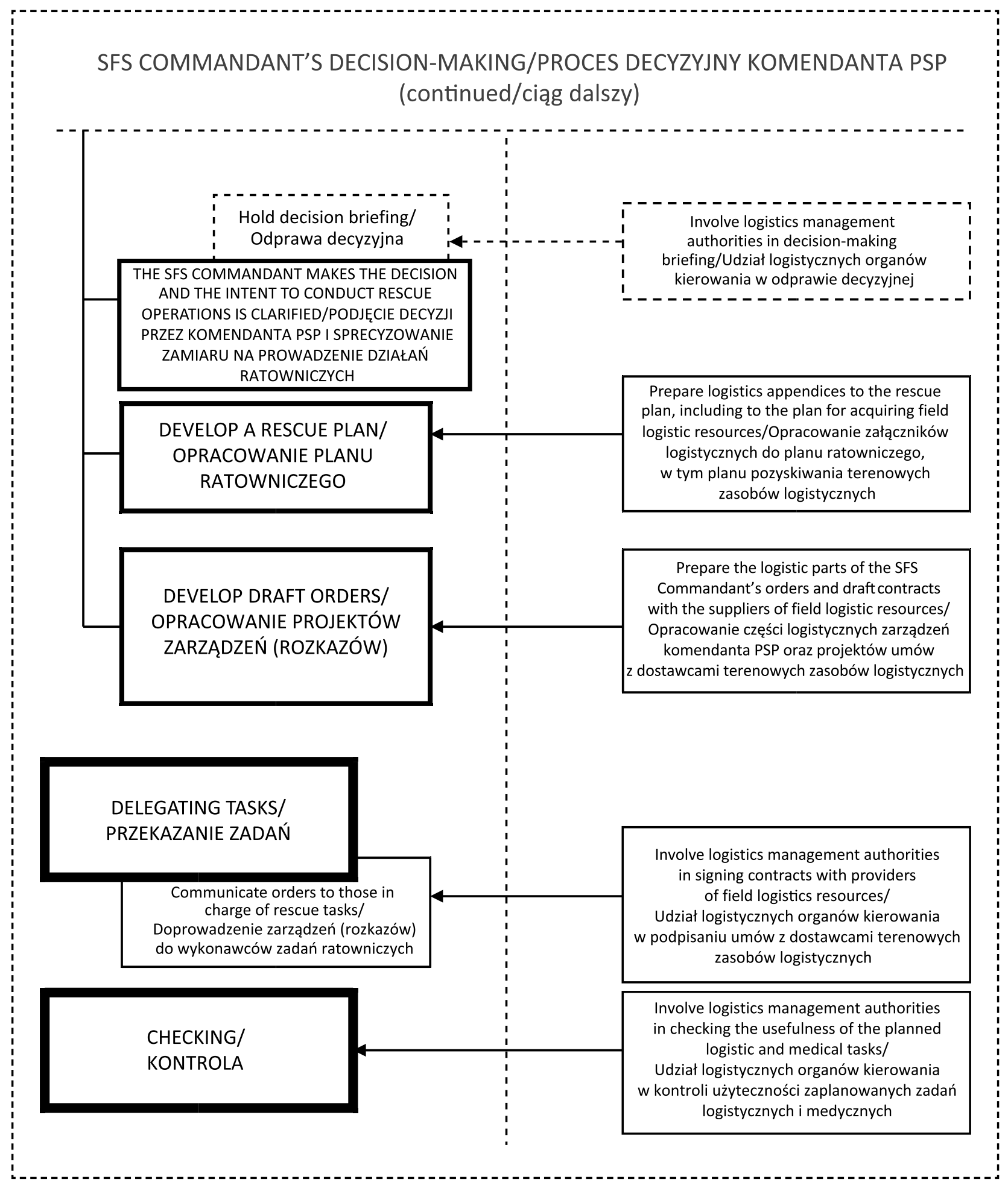

Figure 3. Postulated model of participation in logistics management authorities in the SFS Commandant's decision-making process Rycina 3. Postulatywny model udziału logistycznych organów kierowania w procesie decyzyjnym komendanta PSP w czasie opracowania planu ratowniczego

Source: A system for the comprehensive logistic backup of multi-agent rescue operations. Task 5 Managing logistic resources in rescue operations. 5.3 . Develop a model for using logistic resources in rapidly changing multi-agent rescue operations, E. Nowak (ed.), Wyd. AON, Warsaw 2014, [8, p. 24]. Źródło: System kompleksowego zabezpieczenia logistycznego wielopodmiotowych akcji ratowniczych. Zadanie 5. Zarządzanie zasobami logistycznymi w akcjach ratowniczych. 5.3. Opracowanie modelu wykorzystania zasobów logistycznych w dynamicznie zmieniających się wielopodmiotowych akcjach ratowniczych, E. Nowak (red.), Wyd. AON, Warszawa 2014, [8, s. 24] 
It is a truism to say that the involvement of logistics management authorities is essential in all phases of the SFS Commandant's decision-making process associated with the development of a rescue plan. However, the functionality of this plan, including its logistic appendices (and by extension, the plan for acquiring local logistic and medical resources) depends uniquely on strict adherence to the planning procedures. The authors believe that what might prove particularly useful is the previously mentioned "classic planning procedure". It comprises seven core stages, including:

1. Identifying tasks and setting objectives.

2. Defining conditions for achieving objectives.

3. Analysing the current situation.

4. Listing the planned outcomes.

5. Searching for reasonable (effective) solutions.

6. Selecting the best-possible solution.

7. Developing and reviewing the plan.

Where a plan is developed for acquiring local logistic and medical resources, these stages of planning should proceed as follows:

1. Identifying tasks and setting objectives: define the logistic and medical needs of SFS units in the projected types of long-term rescue operations, and the methods of satisfying such needs.

2. Defining the conditions for achieving objectives: establish the logistic and medical capabilities of SFS units assigned with long-term operations, i.e. define their necessary logistic and medical autonomy, and the dates and methods of providing supplies and logistic services to these units by local business entities.

3. Analysing the current situation: establish the capabilities related to the local logistic and medical resources available in the area (or the vicinity) of the projected long-term rescue operations, the conditions you need to meet to be able to acquire them effectively, and the methods of ensuring the necessary logistic and medical autonomy of SFS units.

4. Listing the planned outcomes: compare various options to arrange for the acquisition of local logistic and medical resources, and provide SFS units with the required logistic and medical autonomy.

5. Searching for reasonable solutions: define the priority criteria for selecting various options to arrange for the acquisition of local logistic and medical resources, and provide SFS units with the required logistic and medical autonomy.

6. Selecting the best-possible solution: select the best-possible option to arrange for the acquisition of local logistic and medical resources.

7. Developing and reviewing the plan: develop plans to acquire local logistic and medical resources in all the projected types of long-term rescue operations, and checking their effectiveness (during SFS Headquarters' exercises).
Twierdzenie, że udział logistycznych organów kierowania we wszystkich fazach procesu decyzyjnego komendanta PSP związanego z opracowaniem planu ratowniczego jest ważny, to truizm. Jednak funkcjonalność tego planu, w tym również jego załączników logistycznych (a więc także planu pozyskiwania terenowych zasobów logistycznych i medycznych), w sposób szczególny zależy od skrupulatnego przestrzegania procedur planowania. Według opinii autorów szczególnie przydatna może okazać się wspomniana wcześniej tzw. „klasyczna procedura planowania”. Zawiera ona siedem podstawowych etapów, do których należą:

1. Identyfikacja zadania i ustalenie celów.

2. Określenie warunków osiągnięcia założonych celów.

3. Analiza aktualnej sytuacji.

4. Zestawienie planowanych efektów.

5. Poszukiwanie racjonalnych (skutecznych) rozwiązań.

6. Wybór najkorzystniejszego rozwiązania.

7. Opracowanie planu i jego weryfikacja.

W przypadku opracowywania planu pozyskiwania terenowych zasobów logistycznych i medycznych powyższe etapy planowania powinny przebiegać następująco:

1. Identyfikacja i ustalenie celów: opracowanie potrzeb logistycznych i medycznych jednostek PSP w prognozowanych rodzajach długotrwałych akcji ratowniczych i sposobów ich zaspokajania w tych akcjach.

2. Określenie warunków osiągnięcia założonych celów: ustalenie wielkości potencjału logistycznego i medycznego jednostek PSP kierowanych do prowadzenia długotrwałych akcji ratowniczych, czyli określenia ich niezbędnej autonomiczności logistycznej i medycznej oraz terminów i sposobów dostarczania środków zaopatrzenia oraz świadczenia usług logistycznych tym jednostkom przez terenowe podmioty gospodarcze.

3. Analiza aktualnej sytuacji: ustalenie wielkości (potencjału) terenowych zasobów logistycznych i medycznych dostępnych w rejonie (w jego pobliżu) prognozowanych długotrwałych akcji ratowniczych, warunków, jakie trzeba spełnić, aby je można było skutecznie pozyskiwać oraz sposobów zapewnienia niezbędnej autonomiczności logistycznej i medycznej jednostkom PSP.

4. Zestawienie planowanych efektów: porównanie wariantów organizacji pozyskiwania terenowych zasobów logistycznych i medycznych oraz zapewnienie jednostkom PSP niezbędnej autonomiczności logistycznej i medycznej.

5. Poszukiwanie racjonalnych rozwiązań: ustalenie priorytetowych kryteriów wyboru wariantów organizacji pozyskiwania terenowych zasobów logistycznych i medycznych oraz uzyskiwania niezbędnej autonomiczności logistycznej i medycznej przez jednostki PSP.

6. Wybór najkorzystniejszego rozwiązania: wyłonienie optymalnego wariantu organizacji sposobów pozyskiwania terenowych zasobów logistycznych i medycznych.

7. Opracowanie planu i jego weryfikacja: opracowanie planów pozyskiwania terenowych zasobów logistycznych i medycznych we wszystkich prognozowanych rodzajach długotrwałych akcji ratowniczych i sprawdzenie (podczas ćwiczeń komendy PSP) ich użyteczności. 
It is a good planning practice to use templates for preparing plans to make the process less time-consuming, and thus to gain more time for conceptual work. Table 1 presents our proposed plan for acquiring local logistic and medical resources.
Dobrą praktyką planowania jest korzystanie z gotowych wzorów dokumentów, dzięki którym można skrócić proces opracowania planów, a zaoszczędzony czas wykorzystać na pracę koncepcyjną. Tabela 1 prezentuje proponowaną przez autorów formę planu pozyskiwania terenowych zasobów logistycznych i medycznych.

Table 1. Plan for acquiring local logistic and medical resources in long-term rescue operations (an example)

Tabela 1. Plan pozyskiwania terenowych zasobów logistycznych i medycznych w długotrwałej akcji ratowniczej (przykład opracowania)

A. FIREFIGHTING OPERATION / AKCJA GAŚNICZA

1. List of planned sources of supplies / Wykaz planowanych źródeł zaopatrzenia

\begin{tabular}{|c|c|c|c|c|c|c|}
\hline \multirow{2}{*}{$\begin{array}{l}\text { No. I } \\
\text { Lp. }\end{array}$} & \multirow{2}{*}{ Type of supply / Rodzaj zaopatrzenia } & \multicolumn{3}{|c|}{ Source of supply / Źródło zaopatrzenia } & \multirow{2}{*}{$\begin{array}{l}\text { Delivery commen- } \\
\text { cement date / } \\
\text { Termin rozpoczę- } \\
\text { cia dostawy }\end{array}$} & \multirow{2}{*}{$\begin{array}{c}\text { Comments / } \\
\text { Uwagi }\end{array}$} \\
\hline & & Name / nazwa & Address / adres & $\begin{array}{l}\text { Telephone / } \\
\text { telefon }\end{array}$ & & \\
\hline 1 & 2 & 3 & 4 & 5 & 6 & 7 \\
\hline 1. & $\begin{array}{l}\text { A. Basic supplies / A. Podstawowe } \\
\text { środki zaopatrzenia } \\
\text { Drinking water / Woda do picia }\end{array}$ & & & & & \\
\hline 2. & $\begin{array}{l}\text { Liquid fuels (diesel fuel/petrol) for motor } \\
\text { vehicles / Paliwa płynne (ON/BS) dla } \\
\text { pojazdów samochodowych }\end{array}$ & & & & & \\
\hline 3. & $\begin{array}{l}\text { B. Specialised supplies / B. Specjali- } \\
\text { styczne środki zaopatrzenia } \\
\text { Firefighting water / Woda gaśnicza }\end{array}$ & & & & & \\
\hline 4. & Fire-extinguishing sand / Piasek gaśniczy & & & & & \\
\hline 5. & $\begin{array}{l}\text { Foam-forming agents / Środki pianotwórcze } \\
\text { a) ARC } 1 \times 1 \mathrm{NT} \\
\text { b) ARC } 6 \times 6 \mathrm{LvF}\end{array}$ & & & & & \\
\hline 6. & $\begin{array}{l}\text { Fire-extinguishing powders / } \\
\text { Proszki gaśnicze } \\
\text { a) BC } \\
\text { b) ABC } 40 \text { Euro }\end{array}$ & & & & & \\
\hline 7. & $\begin{array}{l}\text { Fire-extinguishing gases / } \\
\text { Gazowe środki gaśnicze } \\
\text { a) } \mathrm{CO}_{2} \\
\text { b) Nitrate }\end{array}$ & & & & & \\
\hline
\end{tabular}

2. List of logistic and medical services / 2. Wykaz usług logistycznych i medycznych

\begin{tabular}{|c|c|c|c|c|c|c|}
\hline \multirow{2}{*}{$\begin{array}{l}\text { No. I } \\
\text { Lp. }\end{array}$} & \multirow{2}{*}{ Type of service / Rodzaj usługi } & \multicolumn{3}{|c|}{$\begin{array}{l}\text { Business entity providing the service / } \\
\text { Podmiot gospodarczy świadczący usługi }\end{array}$} & \multirow{2}{*}{$\begin{array}{l}\text { Date of service } \\
\text { commencement / } \\
\text { Termin rozpoczę- } \\
\text { cia świadczenia } \\
\text { usług }\end{array}$} & \multirow{2}{*}{$\begin{array}{c}\text { Comments / } \\
\text { Uwagi }\end{array}$} \\
\hline & & Name / nazwa & Address / adres & $\begin{array}{l}\text { Telephone / } \\
\text { telefon }\end{array}$ & & \\
\hline 1 & 2 & 3 & 4 & 5 & 6 & 7 \\
\hline 1. & $\begin{array}{c}\text { A. Transport services / } \\
\text { A. Usługi transportowe } \\
\text { Passenger transport / Przewóz osób }\end{array}$ & & & & & \\
\hline 2. & $\begin{array}{l}\text { Delivery of fire-extinguishing sand / Dowóz } \\
\text { piasku gaśniczego }\end{array}$ & & & & & \\
\hline 3. & $\begin{array}{l}\text { Evacuation of vehicles and equipment / } \\
\text { Ewakuacja pojazdów i sprzętu } \\
\text { a) towing / holowanie } \\
\text { b) transport by a flat-bed trailer / } \\
\text { przewóz przyczepą niskopodwoziową }\end{array}$ & & & & & \\
\hline
\end{tabular}




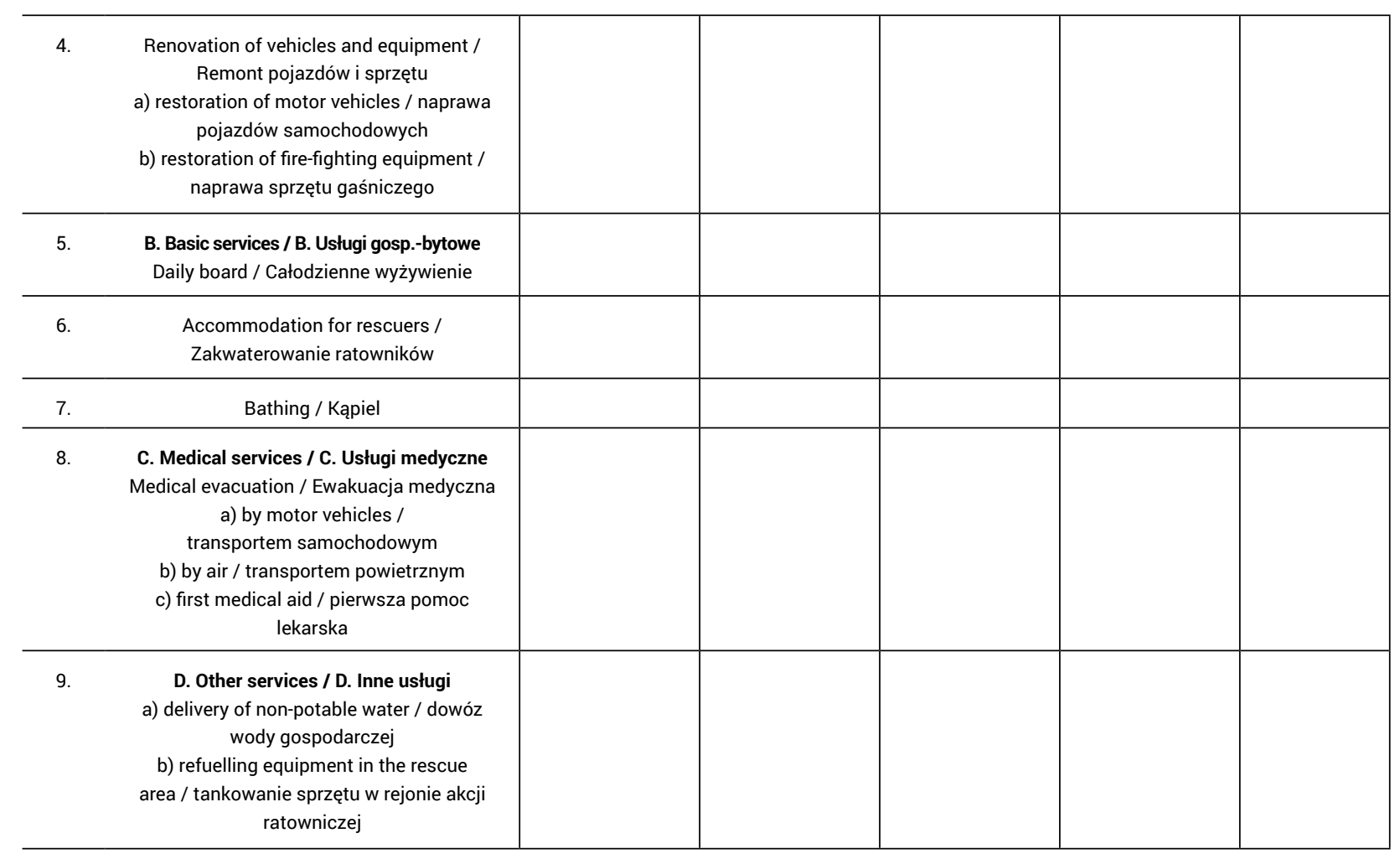

Source: A system for the comprehensive logistic backup of multi-agent rescue operations. Task 1 Internal validation of the system, 1.1. Validation of logistic resource management support software in a multi-agent, long-term rescue operation, E. Nowak (ed.), Wyd. AON, Warszawa 2016, [9, p.13, 23-24].

Źródło: System kompleksowego zabezpieczenia logistycznego wielopodmiotowych akcji ratowniczych. Zadanie 1. Wewnętrzna walidacja systemu, 1.1. Walidacja oprogramowania wspierającego procesy zarządzania zasobami logistycznymi w wielopodmiotowej, długotrwałej akcji ratowniczej, E. Nowak (red.), Wyd. AON, Warszawa 2016, [9, s.13, 23-24].

The effective use of local logistic and medical resources in providing logistic and medical backup to SFS units in long-term rescue operations requires not only good plans for acquiring them from business entities, but also:

- ensuring the necessary logistic and medical autonomy of SFS units assigned to long-term operations,

- applying effective solutions to incentivise business entities - suppliers of local resources.

This study showed that it was necessary to provide SFS units assigned to long-term rescue operations with one- to two days' logistic autonomy [10]. This autonomy should be interpreted as the ability to independently satisfy the basic and specialised supply needs, and to provide logistic services. As far as the ability to provide medical aid is concerned, the authors believe that the autonomy of SFS units should be reflected at least by the ability to provide qualified first aid.

Among the numerous methods to provide incentives, the guarantee of timely payment is of primary importance. It is very important to draw clear lines of responsibility for billing and payments between SFS management authorities and local government authorities. This is necessary, as local resources are often acquired also to arrange for the logistic and medical backup of civilian casualties, save critical infrastructure and cultural heritage and protect the environment.
Skuteczne korzystanie z terenowych zasobów logistycznych i medycznych w procesie zabezpieczenia logistycznego i medycznego jednostek PSP $w$ długotrwałych akcjach ratowniczych wymaga nie tylko dobrych planów ich pozyskania od podmiotów gospodarczych, lecz ponadto:

- zapewnienia niezbędnej autonomiczności logistycznej i medycznej jednostek PSP kierowanych do prowadzenia akcji długotrwałych,

- stosowania skutecznych rozwiązań motywacyjnych dla podmiotów gospodarczych - dostawców zasobów terenowych.

Przeprowadzone badania wykazały, że konieczne jest zapewnienie jednostkom PSP dysponowanym do prowadzenia długotrwałych akcji ratowniczych od jedno- do dwudniowej autonomiczności logistycznej [10]. Autonomiczność tę należy rozumieć jako zdolność do samodzielnego zaspokajania stałych i specjalistycznych potrzeb zaopatrzeniowych oraz świadczenia usług logistycznych. W przypadku zdolności do świadczenia pomocy medycznej autonomiczność jednostek PSP - według opinii autorów - powinna przejawiać się co najmniej w możliwości świadczenia kwalifikowanej pierwszej pomocy.

Wśród wielu metod motywacji gwarancja terminowych rozliczeń finansowych ma znaczenie pierwszorzędne. Niezwykle ważne jest precyzyjne ustalenie podziału odpowiedzialności za rozliczenia 
Other incentives for business entities - in particular to deliver supplies and provide logistic services - might be achieved through such measures as market promotion of the business by using its logo or awarding it with public distinctions (visual advertising).

\section{Results discussion}

The study revealed multiple difficulties with acquiring local resources that were encountered in previous long-term rescue operations conducted in Poland. The main difficulties were attributable to the lack of:

- appropriate regulations on financing rescue operations; division of powers between SFS management authorities and local public administration authorities with regard to the acquisition of such resources,

- gratification for business entities for maintaining readiness to perform logistic tasks for SFS units.

Other difficulties included:

- the long time it took to commence supplies and services by business entities, and issues with obtaining these supplies and services on weekends,

- delays in deliveries of supplies and the provision of logistic services for reasons such as a lack of legal restrictions for the improper performance of contracts,

- a lack of procedures to establish the costs incurred by business entities when providing so-called immeasurable logistic services,

- the need to strictly observe the provisions of the Public Procurement Law Act when developing plans for acquiring local resources.

Well-organised logistic and medical backup for SFS units is one of the prerequisites for effective long-term rescue operations. There is no doubt that the acquisition of local resources required for such backup should proceed in an organised fashion. The authors claim that this can be achieved with the solutions proposed here.

Every logistic backup system, even if well-organised, has a limited capability of quick response. Consequently, it takes some time to make it fully operational. As shown by past experiences related to arranging for the logistic and medical backup of SFS units in long-term rescue operations conducted in the last decades in Poland, this is also true for acquiring local resources. It appears that supplies and logistic services reach SFS units involved in rescue operations no later than on the second day of these operations [10]. Until then, they have to rely on their own resources. Hence, it is necessary to provide them with the logistic and medical autonomy they need. finansowe pomiędzy organami kierowania PSP a terenowymi organami administracji publicznej. Jest to konieczne, bowiem zasoby terenowe często pozyskiwane są również dla potrzeb organizacji zabezpieczenia logistycznego i medycznego ludności poszkodowanej, ratowania obiektów infrastruktury krytycznej, zasobów dziedzictwa kulturowego oraz ochrony środowiska naturalnego.

Skutecznymi motywatorami dla podmiotów gospodarczych - szczególnie do realizacji dostaw zaopatrzenia oraz świadczenia usług logistycznych - mogą okazać się także narzędzia, takie jak: promocja firmy (przedsiębiorstwa) na rynku poprzez używanie jej logo oraz udzielanie jej wyróżnień na forum publicznym (reklama wizualna).

\section{Omówienie wyników badań}

Przeprowadzone badania wykazały wiele trudności związanych z pozyskiwaniem zasobów terenowych, które wystąpiły w dotychczas prowadzonych na terenie RP długotrwałych akcjach ratowniczych. Główne z nich powodowane były brakiem:

- odpowiednich regulacji dotyczących: finansowania akcji ratowniczych; podziału kompetencji pomiędzy organami kierowniczymi PSP i terenowymi organami administracji publicznej w pozyskiwaniu tych zasobów,

- gratyfikacji dla podmiotów gospodarczych za utrzymywanie gotowości do realizacji zadań logistycznych na rzecz jednostek PSP.

Ponadto do innych trudności w tym zakresie należały:

- długi czas uruchamiania dostaw środków zaopatrzenia i świadczenia usług przez podmioty gospodarcze oraz kłopoty z ich egzekwowaniem w weekendy,

- opóźnienia realizacji dostaw środków zaopatrzenia i świadczenia usług logistycznych m.in. na skutek braku prawnych restrykcji za niewłaściwą realizację kontraktu,

- brak procedur ustalania kosztów poniesionych przez podmioty gospodarcze podczas świadczenia tzw. niewymiernych usług logistycznych,

- konieczność ścisłego przestrzegania podczas opracowywania planów pozyskiwania zasobów terenowych postanowień ustawy o zamówieniach publicznych.

Skuteczne prowadzenie długotrwałych akcji ratowniczych determinowane jest $\mathrm{m}$.in. dobrze zorganizowanym zabezpieczeniem logistycznym i medycznym jednostek PSP. Nikogo nie trzeba przekonywać, że pozyskiwanie zasobów terenowych niezbędnych do tego zabezpieczenia powinno być realizowane w sposób zorganizowany. Zdaniem autorów umożliwiają to zaproponowane przez nich rozwiązania.

Każdy - nawet dobrze zorganizowany - system zabezpieczenia logistycznego ma pewną ograniczoną zdolność szybkiej reakcji. Powoduje to, że na jego pełne uruchomienie potrzebna jest pewna ilość czasu. Doświadczenia z organizacji zabezpieczenia logistycznego i medycznego jednostek PSP w długotrwałych akcjach ratowniczych prowadzonych w ostatnich dziesięcioleciach w Polsce wskazują, że dotyczy to także pozyskiwania zasobów terenowych. Okazuje się, że środki zaopatrzenia i usługi logistyczne docierają do jednostek PSP prowadzących działania ratownicze nie wcześniej niż 
The effective acquisition of local logistic and medical resources is an issue which has to be solved already at the stage of planning and concluding civil-law contracts with business entities - the suppliers of these resources. It seems obvious that such contracts should be concluded with trustworthy suppliers on a permanent basis. However, the authors believe that the key factor to ensure the required effectiveness is providing the right incentives for the suppliers of logistic resources to cooperate with SFS management authorities.

Another pertinent issue involves ensuring effective management of supplies and logistic and medical services acquired from local business entities. Those in charge of rescue actions should be supported by properly trained and efficient logistic authorities to make sure such resources are used in line with the standards applicable to the logistic and medical backup of SFS units and other rescue units that support them. The authors recognise the need for the specialised training of SFS logistics experts (e.g. through postgraduate study programmes) to prepare them to arrange for the acquisition of the logistic and medical backup of SFS units in long-term rescue operations.

In light of the study results, the authors have proposed what they believe are innovative solutions for SFS Headquarters. Their application could significantly facilitate the process of providing the logistic and medical backup of rescue units in long-term operations, and consequently increase the efficiency of rescue operations. w drugim dniu tych działań [10]. Do tego czasu muszą one korzystać z własnych zasobów. Konieczne jest więc zapewnienie im niezbędnej autonomiczności logistycznej i medycznej.

Skuteczne pozyskiwanie terenowych zasobów logistycznych i medycznych jest problemem, który musi być rozwiązany jeszcze w okresie planowania i zawierania umów cywilno-prawnych z podmiotami gospodarczymi - dostawcami tych zasobów. Wydaje się oczywiste, że umowy należy zawierać z wiarygodnymi dostawcami, gwarantując im jednocześnie stałą współpracę. Jednak, w opinii autorów, czynnikiem determinującym należytą skuteczność jest właściwa motywacja dostawców zasobów logistycznych do współpracy z organami kierowania PSP.

Sprawą dodatkową, dopełniającą powyższą problematykę, jest zapewnienie skutecznego gospodarowania środkami zaopatrzenia oraz usługami logistycznymi i medycznymi pozyskiwanymi od terenowych podmiotów gospodarczych. Wymagane jest posiadanie przez kierujących działaniem ratowniczym (KDR) odpowiednio wyszkolonych i sprawnie działających organów logistycznych, które zapewnią ich wykorzystanie zgodnie z obowiązującymi normami zabezpieczenia logistycznego i medycznego jednostek PSP oraz wspierających je innych jednostek ratowniczych. Autorzy widzą potrzebę specjalistycznego szkolenia ekspertów ds. logistyki PSP (np. w ramach studiów podyplomowych), które przygotowałoby ich do organizacji zabezpieczenia logistycznego i medycznego jednostek PSP w długotrwałych akcjach ratowniczych.

W odpowiedzi na wyniki przeprowadzonych badań autorzy przedstawili - ich zdaniem nowatorskie - propozycje rozwiązań dla komend PSP. Ich stosowanie w znaczącym stopniu może usprawnić proces zabezpieczenia logistycznego i medycznego jednostek ratowniczych w akcjach długotrwałych, a w konsekwencji wpływać na zwiększenie sprawność prowadzenia tych akcji.

\section{Literature / Literatura}

[1] Doktryna Logistyczna Wojsk Lądowych, DD/4.2. MON/Szt. Gen. WP, DWLąd 33/2007.

[2] Nowak E., Logistyka w sytuacjach kryzysowych, Wyd. AON, Warszawa 2009.

[3] Nowak E., Nowak W., Podstawy logistyki w sytuacjach kryzysowych z elementami zarządzania logistycznego, Wyd. SWSPiZ, Łódź - Warszawa 2009.

[4] Nowak E., Zarządzanie logistyczne w sytuacjach kryzysowych, Wyd. AON, Warszawa 2013.

[5] Ficoń K., Logistyka kryzysowa. Procedury. Potrzeby. Potencjał, Wyd. BEL Studio Sp. z o.o., Warszawa 2011.

[6] Nowak E., Zarządzanie kryzysowe w sytuacji zagrożeń niemilitarnych, Wyd. AON, Warszawa 2007.

[7] System kompleksowego zabezpieczenia logistycznego wielopodmiotowych akcji ratowniczych, Zadanie 5. Managing logistic resources in rescue operations, Stage I - 5.1. Defining methods to calculate the logistic needs of units involved in multi-agent rescue operations, E. Nowak (red.), Wyd. AON, Warszawa 2014.

[8] System kompleksowego zabezpieczenia logistycznego wielopodmiotowych akcji ratowniczych. Task 5 Managing logistic resources in rescue operations. 5.3. Opracowanie modelu wykorzystania zasobów logistycznych $w$ dynamicznie zmieniających się wielopodmiotowych akcjach ratowniczych, E. Nowak (red.), Wyd. AON, Warszawa 2014.

[9] System kompleksowego zabezpieczenia logistycznego wielopodmiotowych akcji ratowniczych. Task 1 Wewnętrzna walidacja systemu, 1.1. Walidacja oprogramowania wspierającego procesy zarządzania zasobami logistycznymi w wielopodmiotowej, długotrwałej akcji ratowniczej, E. Nowak (red.), Wyd. AON, Warszawa 2016.

[10] Chmiel M., Wykorzystanie zasobów terenowych do zabezpieczenia logistycznego jednostek Państwowej Straży Pożarnej podczas długotrwałych akcji ratowniczych, Wyd. ASzWoj., Warszawa 2018. 


\section{List of abbreviations}

$\begin{array}{ll}\text { NFRS } & - \text { National Firefighting Rescue System } \\ \text { SFS } & - \text { State Fire Service } \\ \text { VFS } & - \text { Voluntary Fire Service } \\ \text { DH SFS } & - \text { District Headquarters of the SFS } \\ \text { RH SFS } & - \text { Regional Headquarters of the SFS }\end{array}$

MICHAL CHMIEL, PH.D. ENG. - graduated from first- and secondcycle study programmes at the Main School of Fire Service. A long-time staff member at the CNBOP-PIB's Certification Body, currently heading this Department. He has authored many publications in the local of fire protection. In 2019, he earned the degree of Doctor of Social Sciences in the Security Science discipline. His doctoral dissertation was on the provision of the logistic backup for SFS units during long-term rescue operations.

PROF. EUGENIUSZ NOWAK, D.SC. - professor of Military Science, graduated from a military university in Saint Petersburg and completed a doctoral programme at the General Staff of the Polish Armed Force Academy in Warsaw. He is an expert in national security and logistics, and pioneered such locals as crisis logistics and rescue operation logistics. He has extensive experience in organising exercises related to crisis management and logistics management in crisis situations. Eugeniusz Nowak has authored many research publications on national security and military and rescue operation logistics. He is a professor at the WSB University in Dąbrowa Górnicza.

\section{Wykaz skrótów}

$\begin{array}{ll}\text { KSRG } & - \text { Krajowy System Ratowniczo-Gaśniczy } \\ \text { PSP } & - \text { Państwowa Straż Pożarna } \\ \text { OSP } & - \text { Ochotnicza Straż Pożarna } \\ \text { KP PSP } & - \text { Komenda Powiatowa PSP } \\ \text { KW PSP } & - \text { Komenda Wojewódzka PSP } \\ \text { KDR } & -\end{array}$

DR INŻ. MICHAŁ CHMIEL - absolwent studiów I i II stopnia na Wydziale Inżynierii Bezpieczeństwa Pożarowego Szkoły Głównej Służby Pożarniczej. Wieloletni pracownik Jednostki Certyfikującej CNBOP-PIB, aktualnie kierownik tego działu. Autor licznych publikacji branżowych z zakresu ochrony przeciwpożarowej. W 2019 r. uzyskał stopień naukowy doktora w dziedzinie nauk społecznych $w$ dyscyplinie nauk o bezpieczeństwie. Temat rozprawy autora związany jest z zabezpieczeniem logistycznym jednostek PSP podczas długotrwałych akcji ratowniczych.

PROF. DR HAB. INŻ. EUGENIUSZ NOWAK - profesor nauk wojskowych, absolwent uczelni wojskowej w Sankt Petersburgu oraz studiów doktoranckich w Akademii Sztabu Generalnego Wojska Polskiego w Warszawie. Ekspert w dziedzinie bezpieczeństwa narodowego i logistyki (m. in. prekursor logistyki sytuacji kryzysowych i logistyki akcji ratowniczych). Posiada bogate doświadczenie w organizacji ćwiczeń z zarządzania kryzysowego i zarządzania logistycznego w sytuacjach kryzysowych. Autor wielu prac naukowo-badawczych z zakresu bezpieczeństwa narodowego oraz logistyki wojskowej i logistyki akcji ratowniczych. Pracuje na stanowisku profesora w Akademii WSB w Dąbrowie Górniczej. 